\title{
On Derivative Moral Responsibility and the Epistemic Connection Required for Moral Responsibility
}

William Simkulet

Cleveland State University, w.simkulet@csuohio.edu

Follow this and additional works at: https://engagedscholarship.csuohio.edu/clphil_facpub

Part of the Philosophy Commons

How does access to this work benefit you? Let us know!

Publisher's Statement

This article first appeared in Kilikya Felsef Dergisi, Volume 2, Issue 2, 2015, 67-75.

http://philosophy.mersin.edu.tr/?q=tr/2015-2

\section{Repository Citation}

Simkulet, William, "On Derivative Moral Responsibility and the Epistemic Connection Required for Moral Responsibility" (2015).

Philosophy \& Comparative Religion Department Faculty Publications. 2.

https://engagedscholarship.csuohio.edu/clphil_facpub/2 


\title{
On Derivative Moral Responsibility and the Epistemic Connection Required for Moral Responsibility
}

\author{
William SIMKULET
}

\begin{abstract}
Derivative moral responsibility is not moral responsibility at all. Much of the confusion found in the literature concerning moral responsibility and the free will problem can be traced back to a penchant to reconcile our philosophical theories of moral responsibility with our folk commonsense linguistic accounts of moral responsibility, a tradition that is notable for its utter lack of making two important distinctions - (1) the distinction between derivative moral responsibility and non-derivative moral responsibility (what Galen Strawson calls "true moral responsibility") and (2) the distinction between the scope and degree of one's moral responsibility. ${ }^{1}$ The failure to make such distinctions, ultimately, leads to confusion in interpreting the content of folk intuitions about moral responsibility, and as a result leads many philosophers to adopt watered down, or overly complex theories of moral responsibility. In "The Epistemic Requirements for Moral Responsibility," Carl Ginet fails to make such distinctions, and as a result the requirement he arrives at is unwieldy at best. By making such distinctions, I will provide a much more straightforward account of what moral responsibility requires.
\end{abstract}

Key Words: Moral Responsibility, Free Will, Derivative Moral Responsibility, Commonsense Ethics

There is near unanimous consensus that for an agent to be morally responsible for what she does, she must have a robust form of control over her actions; she must be the author, or cause, of what she is morally responsible for. In contrast, depending on one's view, one can be derivatively morally responsible for things that are partially or completely outside of one's control. This is because derivative moral responsibility is not a king of moral responsibility - rather it is a byproduct of moral responsibility.

\footnotetext{
${ }^{1}$ For an excellent account of the distinction between scope and degree, see Michael Zimmerman 2002. Zimmerman's views on moral luck differ greatly from mine, but the distinction he draws between the scope of one's moral responsibility and the degree of one's moral responsibility is noteworthy.

Simkulet, William (2015) “On Derivative Moral Responsibility and the Epistemic Connection Required for Moral Responsibility”, Kilikya Felsefe Dergisi, (2) pp. 61-75.
} 
According to Aristotle, agents can only be morally responsible for voluntary actions, where an action was voluntary if and only if it satisfied awareness and control conditions. An agent is morally responsible for something id and only if she is in control of her actions and aware of what she does in some relevant sense. In contrast, an agent is derivatively morally responsible for something if and only if she is morally responsible for another thing and there is a relevant causal connection between this other thing and what she is derivatively morally responsible for. Consider the following case:

\section{Reckless Firing}

Susan is a well trained, competent police officer. On New Year's Eve, he fires his pistol into the air to celebrate the new year, fully aware that this action is dangerous and might harm people. As it so happens, one of his shots hits his neighbor, Carol, who was watching fireworks on her balcony.

Here it makes sense to say that Susan is morally responsible for freely choosing to fire her pistol as she is both in control of this action and aware of what she does (and possible results of her choice), but in an important sense she is not aware that she is shooting her neighbor, nor is she in complete control over whether her neighbor gets shot. However, Susan is derivatively morally responsible for shooting her neighbor because her shooting her neighbor is causally connected in a relevant way to something she is truly morally responsible for - her free choice to fire her weapon.

To be morally responsible for something is to have one's moral record affected by that something; in other words to be morally responsible for something is to be the appropriate object of moral praise or blame as a result. ${ }^{2}$ If an agent is derivatively morally responsible for something, her moral record is not further affected - that is to say that she is no more or less blameworthy or praiseworthy as a result. ${ }^{3}$ Michael Zimmerman notably contends that one's moral record includes both a scope of moral responsibility, and a degree of moral responsibility, where the degree is determined by the scope, which includes both moral responsibility

\footnotetext{
${ }^{2}$ An agent may be praiseworthy to a 0 -degree if the agent performs a morally indifferent act; see Derek Pereboom 2005 for such a case.

${ }^{3}$ Zimmerman, in his 2002 article, contends that one's moral record is affected by what one is derivatively morally responsible for. On his view, the scope of one's moral responsibility may grow or shrink based off of what one is derivatively morally responsible for, but one's degree of moral responsibility remains constant.
} 
and derivative moral responsibility. ${ }^{4}$ However, it seems to me that introducing the concept of the scope of one's moral responsibility is nothing more than an attempt to reconcile one's theory with our imprecise folk moral language conventions and adds nothing of value to the discussion of moral responsibility simpliciter. Consider the following cases:

\section{Archery Contest}

Jan intends to win the local archery contest, aims her arrow, fires it, and hits the bull's-eye. Jane also intends to win the contest, aims her arrow, fires it, but misses the bull's-eye because her arrow is intercepted by an unusually thick bird that Jane couldn't have known would swoop by at just that instant. Jen, too, intends to win the local archery contest, aims her arrow, but although she wills herself to fire the arrow, she has a muscle spasm that prevents her from doing so, causing her to misfire. Let's say such muscle spasms routinely, but sporadically, occur in archers who engage in the sort of strenuous exercise that all of the archers in the contest engage in. Finally, Jenny intends to win the local archery contest, aims her arrow, fires it, but misses the bull's-eye because, unbeknownst to her, her eyesight has recently been impaired in such a way that she had no reason to suspect. Jan wins the archery contest.

Jan, Jane, Jen, and Jenny each exert the same control over their actions, and each is has the same awareness of what they do; as such it strikes me that it makes sense to say that each of them is equally morally responsible for what they've done. However, to an impartial third party observer not privy to the details, Jan the only contestant to hit the bull's-eye is apparently more praiseworthy than the rest. Jan is derivatively morally responsible for winning the contest because her winning of the contest is causally connected to something she was in sufficient control of.

What is Jan truly morally responsible for? Jane's case demonstrates that whether or not one's perfectly aimed arrow hits the bull's-eye is a matter of luck insofar as it depends upon factors completely outside of the control of the archer. Many philosophers claim that the regress ends here - that Jan is morally responsible for firing her arrow. This is a mistake - Jen's case demonstrates that Jan is also derivatively morally responsible for her acting firing the arrow because whether or not her body responds to her will is not up to her (insofar as sporadic muscle spasms undermine the normal causal effect one's will has on one's body).

${ }^{4}$ See Zimmerman 2002. 
If this is right, Jan is morally responsible for her will, which can be described as her acting with certain intentions and desires - her intention to win the tournament, her desire to participate, etc. This is something that each of the contestants has in common and thus each can be said to be equally morally responsible. I contend that moral agents (like us) are only morally responsible for acts of the will - it is the only thing we're said to have complete control over - we are the sole author of our own wills - and thus the only thing that one can be held morally responsible for. $^{5}$

Jenny's case is perhaps the most strange, as the deficiency that led to her missing is located before her will, not after. This is to say that the reason she failed to hit the bull's-eye is a byproduct not of resultant luck, but on circumstantial luck. Through no fault of her own, she contingently lacks an ability the other archers have - good eyesight, and she is utterly ignorant of this fact. If she was not ignorant, she could have acted differently which may have resulted in her hitting the bull's-eye. She exerts the same control over what she does as others, and she has the same awareness of what she tries to do as others; and this is what matters.

There are, I think, two possible objections to this account - Some might contend that (A) one's moral responsibility, in particular the blame or praise one deserves, is determined by the consequences of one's actions; and (B) this account contradicts our commonsense moral language - after all, we say things like "Jones is morally responsible for killing Smith", and "What makes Jones blameworthy for killing Smith is that he did something terrible - he killed Smith." The contention that this account is inconsistent with everyday moral language shouldn't be taken as evidence that the view is wrong because such commonsense moral language utterly fails to capture all relevant respects of moral responsibility -

\footnotetext{
${ }^{5}$ Those scholars familiar with the problem of moral luck should take me to task for contending that control is undermined by resultant luck - luck in the consequences of one's willings, or actions, but for not asserting the same about situational luck. The problem of situational luck is, I think, a mistake - at least in this context. This is because, intuitively, no one is every justly held morally responsible for the circumstances they find themselves in, and no one has any immediate control over the character they act with at any given time, nor do we often have control over the causal processes by which we choose (those who flip coins to make difficult decisions being obvious exceptions). The only sense in which situational luck matters is that it gives an agent a different quantity or quality of opportunities to act morally in. Luck in this sense matters only if one is concerned with the quantity of marks on one's moral record. In this paper, and in everyday commonsense moral language, we are not, so situational luck doesn't undermine the control required for moral responsibility.
} 
as noted earlier, it fails to distinguish between moral responsibility simpliciter and derivative moral responsibility, to distinguish degree from scope, and furthermore to distinguish between differences in degree of moral blame or praise. Consider the following two cases:

\section{Jones 1}

Jones1, a recovering alcoholic, keeps a bottle of wine in his study that he has poisoned, a reminder that alcohol is poison. He tries to put alcohol out of his mind at every step, and rarely thinks about the wine anymore. Jones1's cousin, Smith1, comes to visit, and his flight arrives early. He informs Jones 1 of this, who tells Smith1 where his hidden key is, and tells Smith1 "my home is your home", which Smith1 understands to mean that he can help himself to the food and drink in the house, which is pretty much what Jones 1 means when he says this. Jones 1 fails to mention the bottle of wine because he didn't think of it. Smith1 finds the wine and drinks some.

\section{Jones 2}

Jones2 knows his cousin Smith2 is an alcoholic. He picks up a bottle of wine, poisons it, and hides it in his study, believing that if Smith2 finds the bottle and drinks from it, that he "deserves what he gets". Smith2 arrives early and calls Jones 2 who tells him where to find the key, and that "my home is your home." Smith2 finds the wine and drinks some.

Although both Jones1 and Jones2 can be said to have killed their cousin, it seems uncontroversially true that they're differently morally responsible for what they've done. Specifically, Jones1 is prima facie not morally blameworthy for what he's done (insofar as he didn't intend harm, nor did he believe any harm would arise from the action he took for symbolic reasons), and that Jones2 is prima facie morally blameworthy for what he's done (insofar as he intended harm to befall Smith2, or at the very least acted in a way in which he believed had an unreasonable risk of causing harm to Smith2). For those who contend that moral responsibility is, in part, decided by the actual outcome, it seems that Jones 1 and Jones 2 would need to be equally morally blameworthy at least in this regard - but Jones1 doesn't seem morally blameworthy in any substantial sense. There is, of course, good reason for one to judge Jones 1 and Jones 2 to be similarly morally blameworthy on the basis of the consequences alone if we don't have any other information, but surely if we came to know the whole story any initial criticism of Jones1 would be revise because although Jones1's action of poisoning the wine caused a natural evil - Smith1's death, the will behind Jones1's action lacked a 
morally relevant epistemic connection to Smith1's death, or any similar harm. By epistemic connection, I mean a contingent similarity or relationship between the relevant epistemological content of one's will and the consequences one believes one's will might result in.

Consider the epistemic content of Jones2's will; he knows what poison is, he knows what he is doing, he knows Smith2 will likely drink from the bottle, he knows that if Smith2 does, he will be poisoned, etc. As it so happens, this epistemic content - specifically that concerning how Jones2 thinks events will play out - bears a striking and robust similarity to the actual outcome. Indeed, this similarity is no coincidence - Jones 2 chooses his actions with this result in mind.

However, I contend that what makes Jones2's action morally wrong isn't just the fact that, in the actual world, Smith2 is poisoned, rather what matters is the epistemic connection between Jones2's will and every world he believed his action could bring about. What makes Jones2's will morally blameworthy is that he acted in such a way that he believed would likely cause evil believing he could have acted otherwise. ${ }^{6}$

It seems to me that there are two ways in which one's epistemological content can affect one's degree of blame or praise for one's willings - the expected probability of one's will to affect the world in such and such a way, and the desire that one's will affects the world in such and such a way. Compare a hunter who believes that there is a $1 \%$ chance the thing she is aiming at is a person (and not a deer) and shoots (hoping for a deer), to a hunter who believes that there is a $50 \%$ chance the thing she is aiming at it a person and shoots (still hoping for a deer). Clearly the greater risk of harm makes the latter hunter's will blameworthy to a higher degree than the former hunter's. ${ }^{7}$ This is because out of all of the worlds in question - the worlds the agent thinks possible, the worlds the agent hopes possible (but doesn't necessarily think possible), and the worlds the agent fears possible (but again, doesn't necessarily think possible), there are more worlds were the second hunter causes more harm than the first, and thus the second

${ }^{6}$ Those who believe that Frankfurt's infamous 1969 argument against the requirement of alternate possibilities succeeded may ignore this condition. I believe that the Kane/Widerker objection is sufficient to show Frankfurt's argument fails, and thus this condition is necessary, but any further discussion on the matter is outside of the scope of this paper. See Kane 1985, 1996; Widerker 1995.

${ }^{7}$ Presumably there is some level of risk that is morally acceptable, given the expected award, but the weighing of such considerations is outside the scope of this paper. 
hunter is blameworthy to a higher degree (because the epistemic content of the hunter's will is mirrors the comparably large amount of evil found in these worlds she expected, hoped, or feared possible). Now consider a third hunter who also believes that there is a $1 \%$ chance that thing she is aiming at is person, and shoots that thing hoping it's an innocent person. What makes the third hunter more blameworthy than the first is that in all worlds she hopes possible, her will causes her to kill someone. In contrast, in all of the worlds the first hunter fears possible, her will causes her to kill someone. I contend that wanting, or hoping, to cause an evil is prima facie more morally blameworthy than being afraid of causing said evil, and because of this, the epistemic connection between the third hunter's will and the evil in the worlds she thought, hoped, or feared possible is higher than between the first hunter's will and the evil thought, hoped, or feared possible. Although both hunters share the same set of worlds in question, the order of their preference in regards to these worlds is different, and there is a greater epistemic connection to worlds one expects possible than one hopes and fears possible, and a greater epistemic connection to worlds one hopes possible than fears possible. ${ }^{8}$

Finally, consider a hunter who doesn't care what she hits. It seems to me prima facie plausible to say that the epistemic connection between this agent's will and the harm she thinks, hopes, or fears possible is lower than the third hunter, but higher than the first. However, I think this is a mistake for three reasons. First, it seems to me prima facie morally true that doing the right thing for the wrong reason is morally wrong, so the agent who acts without a reason forfeits any potential counterbalancing praise she might get from the probability of her doing the right thing (because everything she does will be, by definition, wrong). Second, it seems perfectly plausible to say that the third hunter intends to bring about one particular kind of bad outcome (harm a person), but not necessarily others (harm an endangered species, harm the environment, etc.), while this last hunter risks all such harms equally. She may be more blameworthy than the second in the same way the rapist who rapes a million people is more blameworthy than the murderer who kills only one. Thirdly, by not caring about the potential outcomes, the agent shouldn't be judged on the ill of her expected possible outcomes because she doesn't restrict (or even consider) worlds in this way. Because she fails to

${ }^{8}$ It seems to me perfectly intuitively plausible to say that the third hunter, who hopes to kill a human despite believing that it is severely unlikely, is as morally blameworthy as a fourth hunter who hopes to kill a human while believing that there is a good chance that what she's shooting at is a human, but I will not argue for such a position here. 
distinguish between the worlds she cares about and the worlds she doesn't (those she believes impossible, etc.), she can be held blameworthy for the epistemic connection (of indifference) to all of these worlds. As such, the cumulative evils and no counterbalancing good aspects of this last hunter seem to make her substantially more morally blameworthy than we might initially suspect. ${ }^{9}$

On this view, what makes an agent morally blameworthy is the epistemic connection her will has to the harm at the worlds she expects, hopes, and fears possible, where the actual world is (at best) one of many worlds, and isn't any more or less morally relevant than any other in the set. Unlike those who hold that one's praise or blame is determined by the consequences of one's actions, this view removes luck from the picture, and explains why Jan, Jane, Jen, and Jenny are all equally morally responsible despite having vastly different outcomes. It is, however, true that the bad or good consequences that end up occurring do play a part in determining the rightness or wrongness of the agent's action. To the extent that an agent's will has a high success rate, any given good or bad outcome is evidence that the agent willed that outcome, and this evidence is often what prompts our moral investigations and judgments. Furthermore, by appealing to the epistemic connection between one's will and the worlds the agent expects, fears, and hopes possible, it is easy to articulate what makes two agents who cause the same outcome differently morally responsible - the degree of their praiseworthiness or blameworthiness depends upon their epistemic connections. I call this view, that moral agents are morally responsible for their wills, moral intentionalism.

In light of this account of what agents are morally responsible for (their will), what they're derivatively morally responsible for (that which their will causes, directly or indirectly), and what makes the agent more or less blameworthy or praiseworthy (the connection between the epistemic content of one's will and the expected, hoped, or feared possible worlds), we're in a goods position to better

\footnotetext{
${ }^{9}$ If you believe that it is impossible for an agent to be indifferent in this way, ignore all discussion of this last hunter. It seems to me that compatibilists and several event-causal incompatibilists contend that moral agents can only act for reasons, and this hunter seems to act only for no reason. However, at least agent-causal indeterminists seem to leave this possibility open.
} 
judge problematic examples. Consider the following two cases from Carl Ginet's "The Epistemic Requirements for Moral Responsibility":

Simon enters the hotel room he has just checked into and flips what appears to be, and what he takes to be, an ordinary light switch, but, to his surprise and consternation, the flipping of the switch sets off a loud fire alarm. It seems that, because he did not know that his flipping the switch would have this unfortunate consequence, it would be wrong to feel indignant with him for bringing about that consequence (Ginet, 269).

Consider a revised version of our example of Simon and the switch that set off a fire alarm. Suppose that the switch did not look at all like an ordinary light switch - the whole thing was red, much larger than a typical light switch, and located fairly high up on the wall. Moreover, immediately below it in large white letters on a red background were the words "FIRE ALARM". Simon is a normal adult whose native language is English and he has been about in the world enough to know about the typical appearance of light switches and about fire alarms. But so intent was he on finding a light switch that he somehow failed to notice the words "FIRE ALARM", or to take in the significance of the conspicuous differences between the switch he pulled and a typical light switch, and thought that the switch he flipped would just turn on a light. As Simon himself later confessed in making profuse apologies, his failure to notice or heed those things was inexcusable. A certain amount of indignation towards him, for his causing the alarm to go off, would be deserved (though, of course, not as much as if he had intentionally set it off) (271).

In the first version of the Simon case, Ginet's assessment seems intuitively plausible - for the moral intentionalist, Simon is morally responsible for willing to flip the switch (in that situation), and is derivatively morally responsible for flipping the switch, for setting off the fire alarm, etc. What makes it inappropriate to "feel indignant" about his action is that Simon lacked any reasonable expectation to believe the switch would set off the fire alarm - this is to say that in all of the worlds he expected, hoped, or feared, there are relatively few (if any) worlds where his pulling the switch causes harm, let alone harm of this kind (disturbing the hotel occupants and firefighters).

The intuitive plausibility of Ginet's account of the first version stands in sharp contrast to his account of the second version. Oddly, Ginet seems to want to hold Simon v2 responsible for not paying appropriate attention to the switch, which was labeled "FIRE ALARM", when he was intent on flipping a light switch. Perhaps Simon v2 was in a relatively well-lit room but wanted a bit more light; set this aside. Ginet claims that Simon v2 is morally responsible for flipping 
the switch under these conditions, but he also stipulates that at the time he flips the switch, he is unaware of these situations. Simon v2 appears to have no more reasonable expectation that he would set off the fire alarm in this case than in the first case. What Ginet claims makes Simon responsible for turning on the fire alarm in this case, but not the previous one, is that his ignorance is morally culpable ignorance. That is to say, apparently, Ginet believes that Simon should have read the words "fire alarm" before flipping the switch. But despite Simon's confession of irresponsibility, it is easy to construct a back story where his ignorance is not culpable: (a) If the room was dark then Simon v2 wouldn't have been able to read the label on the switch, (b) he might have been distracted by a phone call or stubbed toe, or (c) he might have never considered the possibility that this hotel that he is unfamiliar with would have placed a fire alarm where a light switch would traditionally have been placed.

Still, it seems prima facie plausible that one could articulate conditions under which Simon should have known the switch was a fire alarm:

\section{Simon v3}

Simon v3 speaks and reads fluent English and chooses to stay at a hotel because of its famous architect who was infamously committed to an insane asylum for his bizarre architectural decisions. During the day Simon v3 gets caught up in exploring his hotel room, flipping various switches and opening various secret compartments, and in his fervor he flips the switch labeled "FIRE ALARM" without reading it.

Here it makes sense to say Simon v3 is morally responsible for his ignorance (not reading the switch label before flipping it), and derivatively morally responsible for setting off the fire alarm. Because Ginet doesn't adequately distinguish between moral responsibility, and derivative moral responsibility, he tasks himself to provide a theory where Simon v2 is morally responsible for tripping the fire alarm, rather than a theory of why he is morally responsible for his ignorance or to what degree he's responsible for said ignorance. For the moral intentionalist, if Simon v2 acted carelessly (without the proper regard to consequences), or if he acted fully aware of the risk of pulling the switch, there is a robust epistemic connection between his will (to pull the switch w/o reading the sign) and the evils that doesn't exist in the first Simon case.

However, Ginet tasks himself to articulate a criterion for moral responsibility that would show Simon v2 is morally responsible for not only his will to pull the 
switch (while having certain beliefs), but that he is also morally responsible for his setting off the fire alarm. He calls this criterion the epistemic requirements for moral responsibility:

$\mathrm{S}$ is blameworthy for bringing about (or failing to prevent) harm $\mathrm{H}$ by moving (or omitting to move) in way $\mathrm{M}$ at $\mathrm{t} 1$ only if: [the $C D O$ condition] at some time $\mathrm{t} 0$, not later than $\mathrm{t} 1$, either (i) $\mathrm{S}$ acted in a certain way $\mathrm{W}$ such that it was open to $\mathrm{S}$ at $\mathrm{t} 0$ not to act in way $\mathrm{W}$ then and, had S not acted in way $\mathrm{W}$ then, it would have been open to $\mathrm{S}$ at $\mathrm{t} 1$ not to make (or to make) $\mathrm{M}$ or any (some) other movement then that would bring about (prevent) $\mathrm{H}$, or (ii) $\mathrm{S}$ did not at t0 act in a certain way W such that it was open to $\mathrm{S}$ at $\mathrm{t} 0$ to act in way $\mathrm{W}$ then and, had $\mathrm{S}$ acted in way $\mathrm{W}$ then, $\mathrm{S}$ would have had it open to her at t1 not to make (or to make) M or any (some) other movement then that would bring about (prevent) $\mathrm{H}$; and [the epistemic condition] either (i) $\mathrm{S} \mathrm{knew*} \mathrm{at} \mathrm{t0} \mathrm{that} \mathrm{her} \mathrm{acting} \mathrm{(or} \mathrm{omitting} \mathrm{to} \mathrm{act)} \mathrm{in} \mathrm{way} \mathrm{W}$ would or might bring about (or, in the case of omission, prevent) a harmful act (or omission) of the sort $\mathrm{S}$ subsequently committed at t1, or (ii) $\mathrm{S}$ did not at t0 know* this but there is a sequence of one or more acts (or omissions) that ends with the act (or omission) at t0and is such that (a) each member before this last member benights the subsequent member, (b) the first (earliest) member of the sequence was not a benighted act (or omission)-at the time of it S knew* that it would or might lead to the sort of harm it in fact led to, namely, the benighted act (or omission) that is the next member of the sequence, and (c) at the time of each benighted act (or omission) in the sequence $\mathrm{S}$ should have known* (was blameworthy for not knowing*) that it would or might lead to the sort of benighted act (or omission) that it in fact led to in the next member of the sequence (276-277).

This requirement is full of technical terminology. To know* $\mathrm{X}$, for Ginet, is to actively believe X true (270). The term "benight" comes form Holly Smith's 1983 article "Culpable Ignorance"; for Ginet one action benights another if and only if the moral responsibility for the latter is determined by the culpable ignorance of the former. Finally, the CDO condition is his version of the principle of alternate possibilities, roughly requiring that the agent in question have the ability to bring about a different outcome had they acted otherwise. In light of this, here is a more condensed version of Ginet's principle:

An agent $\mathrm{S}$ is blameworthy for bringing about harm $\mathrm{H}$ by doing motion $\mathrm{M}$ at $\mathrm{t} 1$ only if: [the $\mathrm{CDO}$ condition] at some time $\mathrm{t} 0$, no later than $\mathrm{t} 1, \mathrm{~S}$ acted in a certain way $\mathrm{W}$ such that it was open to $\mathrm{S}$ at $\mathrm{t} 0 \mathrm{not}$ to act in way $\mathrm{W}$ then and, had $\mathrm{S}$ not acted in way $\mathrm{W}$ then, it would have been open to $\mathrm{S}$ at $\mathrm{t} 1$ not do $\mathrm{M}$ or another movement then that would bring about $\mathrm{H}$; and [the epistemic condition] either (i) $\mathrm{S}$ knew* at t0 that her acting in way $\mathrm{W}$ would or might bring about a harmful act of the sort $\mathrm{S}$ subsequently committed at $\mathrm{t}$, or (ii) $\mathrm{S}$ did not at t0 know* this but there is a 
sequence of one or more acts that ends with the act at $t 0$ and is such that (a) each member before this last member benights the subsequent member, (b) the first (earliest) member of the sequence was not a benighted act (or omission)-at the time of it S knew* that it would or might lead to the sort of harm it in fact led to, namely, the benighted act that is the next member of the sequence, and (c) at the time of each benighted act in the sequence S should have known* (was blameworthy for not knowing*) that it would or might lead to the sort of benighted act that it in fact led to in the next member of the sequence.

While this version is significantly more manageable, (ii) makes up over half of the text. But (ii) doesn't concern moral responsibility, but a kind of derivative moral responsibility. Earlier I contended that an agent is derivatively morally responsible for an action if and only if she is morally responsible for another thing, and there is a causal connection of a relevant sort between that other thing and what she is derivatively morally responsible for. The kind of connection Ginet articulates in (ii) here is a blameworthy ignorance - he accounts for other kinds of derivative moral responsibility earlier in this requirement. Consistent with our folk moral linguistic practices, Ginet contends that agents can be morally responsible simpliciter for the consequences of their actions (in this case, harm $\mathrm{H}$ ), and their bodily movements (in this case, M). However cases like those of Jane, Jen, and Jenny show that whatever control one has over the harms one does, and one's bodily movements, is insufficient for moral responsibility. Furthermore, such an account utterly fails to explain how an agent is morally responsible in those cases where their actions go awry - again, Jane, Jen, and Jenny are all prima facie praiseworthy for their actions despite their failures.

Ginet believes he's captured the epistemic conditions for moral responsibility, but it falls far short of this goal. It doesn't talk about the epistemic conditions for moral responsibility, rather it only talks about the epistemic conditions for moral responsibility for a given actual harm $\mathrm{H}$. It equivocates between moral responsibility - which requires control, and derivative moral responsibility, which requires no control over what happens past the initial action (for Ginet, $\mathrm{M}$, for the intentionalist - the agent's intention, or willing to M). Even worse, Ginet's CDO condition concerns whether or not the agent can bring about alternate outcomes, not whether or not the agent has alternate possibilities. Harry Frankfurt famously argues that moral responsibility doesn't require alternate outcomes, but fails to show that moral responsibility doesn't require alternate possibilities, where the possibilities in question involve the epistemic content of the agent's will, not the actual outcomes of the agent's will. Imagine a fifth archery competitor, June, who 
is as skilled as the other four, but rather than intend to win the match, she intends to throw the match. Unbeknownst to her, her bow has also been sabotaged by the mysterious Black such that if June attempted to hit the bull's-eye, her arrow would have swerved and hit the ground, but if she hadn't it would have fired normally. On Ginet's view, June isn't blameworthy because no matter what she willed, she would have missed the target. Yet June's will to throw the match has a direct, non-arbitrary causal connection to her missing the bull's-eye such that it makes sense to say that she is blameworthy for it. Finally, Ginet's account utterly fails to explain what makes that thing the agent is morally responsible for more or less morally good or bad - one might assume the weight of the harm determines the degree of responsibility, but there are too many counterexamples to this view to ascribe it to Ginet.

To better address cases like these, consider the following accounts:

\section{What moral responsibility requires:}

A moral agent $\mathrm{S}$ is morally responsible for some action $\mathrm{A}$ [where $\mathrm{A}$ is a free willing] if and only if the agent has complete control over that action, where having complete control of this kind requires (a) alternate possibilities, (b) that it was within S's power to do A for a reason.

\section{What moral blame, praise, and neutrality require:}

A moral agent $\mathrm{S}$ is morally blameworthy or praiseworthy for an action A if and only if there is at least one epistemic connection between S's reasons for acting and the realm of possible or impossible worlds $\mathrm{S}$ believes, hopes, or fears are within her grasp. (If $\mathrm{S}$ fails to narrow the realm of possible worlds, she treats all worlds as if they are within her grasp). $\mathrm{S}$ is blameworthy to the extent to that the (relevant) epistemic content behind A mirrors evils in these worlds either through design or risk, and is praiseworthy to the extent to that the (relevant) epistemic content behind A mirror the good in these worlds either through design or risk, factoring in the least blameworthy and least praiseworthy alternatives ${ }^{10}$. An action is neutral if and only if the act is morally indifferent (when all possible alternatives are morally equivalent).

\footnotetext{
${ }^{10}$ This conditional is based on Michael Otsuka's principle of avoidable blame (and its counterpart, a principle of avoidable praise). See Otsuka 1998, Simkulet 2015.
} 


\section{What derivative moral responsibility requires:}

A moral agent $\mathrm{S}$ is derivatively morally responsible for something $\mathrm{X}$, where $\mathrm{X}$ is an action, character trait, event, situation, object, etc., if and only if there is a robust causal connection between some action $\mathrm{A}$ that $\mathrm{S}$ is morally responsible for, and X, such that A caused X either directly (such as how one's will to lift one's arm causes one's body to lift one's arm), or indirectly (such as how one's will to kill the pull the trigger to kill the president caused one's body to pull the trigger which caused the president to die, which caused the nation to grieve).

On this account, one can be derivatively morally responsible for something that it would be improper to be blameworthy for (such as Simon's being derivatively morally responsible for pulling the fire alarm in the first version). Furthermore, unlike Ginet's account, this view articulates what makes an action neutral, or praiseworthy or blameworthy to some degree. But the most important aspect of this view is its uncomplicated account of moral responsibility - moral responsibility requires complete control, the kind of control we are said to have over our will alone (when our will is free). Every other sort of control, no matter how contingently reliable, is mitigated, or partial control - that is to say there is something other than us that may interfere with our will producing the desired outcomes. For one to be morally responsible for one's bodily movements regardless of whether they're intentional, or the movements of one's arrow, or for one's misinformation that leads to mistake, and the like is to hold one morally responsible for something one has no control over, and this - despite the consistency with our folk moral linguistic practices - is absurd. One can only be morally responsible for what one controls. However, to the extent to which one is derivatively morally responsible for other things, it makes sense, in layman's terms, to say that one is morally responsible for such things. Such talk, at best, captures the scope of one's moral responsibility, which extends beyond one's will to its consequences. Talk about scope is, I think, justified because of the role in which agents who are not privy to other's inherently private will must reconstruct, from their consequences and behavior, their own estimation of another's will. But this endeavor concerning the conditions under which judging people morally responsible is justified, not the conditions under which an agent is truly morally responsible.

William Simkulet, University of Wisconsin-Marshfield, Wood Country, USA 


\section{REFERENCES}

Aristotle, 2001, Nicomachean Ethics in The Basic Works of Aristotle ed. Richard McKeon. Randomhouse

Frankfurt, Harry G., 1969, "Alternate Possibilities and Moral Responsibility", The Journal of Philosophy, Vol. 66, No. 23, pp. 829-839.

Ginet, Carl, 2000, “The Epistemic Requirements for Moral Responsibility," Nous, Vol. 34, Supplement Philosophical Perspectives, 14, Action and Freedom, pp. 267-277.

Kane, Robert, 1985, Free Will and Values. Albany: State University of New York Press.

Kane, Robert, 1996, The Significance of Free Will. New York: Oxford University Press.

Otsuka, Michael, 1998, "Incompatibilism and the Avoidability of Blame", Ethics, Vol. 108, No. 4: 685-701.

Pereboom, Derek, 2005, “Defending Hard Incompatibilism,” Midwest Studies 29, pp. 228-47.

Smith, Holly, 1983, "Culpable Ignorance", The Philosophical Review 97, pp. 543-571.

Strawson, Galen, 1994, “The Impossibility of Moral Responsibility,” Philosophical Studies 75, pp. 5-24.

Widerker, David, 1995, "Libertarianism and Frankfurt's Attack on the Principle of Alternative Possibilities," The Philosophical Review 104, pp. 247-261.

Simkulet, William, 2015, "On Robust Alternate Possibilities and the Tax Evasion Case," Southwest Philosophy Review, 31-1, 101-107.

Zimmerman, Michael J., 2002, “Taking Luck Seriously”, The Journal of Philosophy, Vol. 99, No. 11: 553-576. 